\title{
DÜBLIN
}

Technological University Dublin ARROW@TU Dublin

2013-09-02

\section{Small-Scale Wind Turbines: an Appraisal}

Tony Kealy

Technological University Dublin, tony.kealy@tudublin.ie

Follow this and additional works at: https://arrow.tudublin.ie/engschmanconn

Part of the Electrical and Electronics Commons, and the Manufacturing Commons

\section{Recommended Citation}

Kealy, T. : Small-Scale Wind Turbines: an Appraisal. UPEC 2013: 48th. International Universities' Power Engineering Conference, Dublin, Ireland, 2nd - 5th September, 2013.

This Conference Paper is brought to you for free and open access by the School of Manufacturing and Design Engineering at ARROW@TU Dublin. It has been accepted for inclusion in Conference Papers by an authorized administrator of ARROW@TU Dublin. For more information, please contact arrow.admin@tudublin.ie, aisling.coyne@tudublin.ie,gerard.connolly@tudublin.ie.

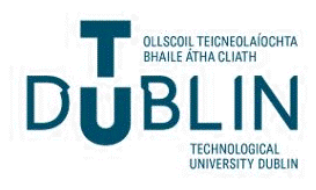




\title{
Small-Scale Wind Turbines: An Appraisal
}

\author{
Tony Kealy \\ Dublin Institute of Technology \\ E-mail: tony.kealy@dit.ie
}

\begin{abstract}
This research seeks to evaluate the economic benefits to be gained by installing a small-scale wind turbine for a customer with a three-phase electrical supply requirement. The evidence for the claims made in this paper is obtained by using actual data obtained from the installed equipment over a three year period. The objective is to accurately appraise the financial investment using real data. There appears to be limited studies conducted into this type of research, possibly because the renewable energy sector is in the infancy stage in the host country, Ireland. There are some wind energy installations with financial appraisal techniques based on modeled data, which may, or may not, be accurate. The study concludes by claiming that the financial benefits of the wind energy turbine installation had disappointing results when compared to predicted benefits based on modeled data.
\end{abstract}

Index Terms-Wind Turbines, Financial Appraisal, Feed-in Tariffs.

\section{INTRODUCTION}

The majority of Ireland's generated electricity comes from fossil-fuel driven plants. In line with European Union directives, Ireland has committed itself to adjusting this policy by agreeing new climate and energy targets [1] (http://www.dcenr.gov.ie). It is hoped by the year 2020 that the renewable contribution to electricity production will have increased to $40 \%$. Of this figure, it is envisaged that 35 per cent will come from wind energy. To aid and enhance this strategy, the Irish government has put incentives in place to encourage small scale wind energy projects. It appears that now a significant number of small businesses and households have embraced these types of wind energy projects possibly without fully investigating the consequences of adopting such incentives.

Financial appraisals of small scale individual projects appear to be sparse, understandably because of the early stage of development of this industry life cycle. A paper by Kelleher and Ringwood (2009) [2] presents a method to estimate the economics of renewable microgeneration of electricity from wind and solar energy sources using a computer programme. The authors [2] use variables such as a range of feed-in tariffs, government incentive schemes, and the cost of capital borrowing to determine payback periods. They concluded by claiming that payback periods can vary greatly depending on the location, installation, and economic variables. A further study by Walters and Walsh (2011) [3] examines the financial performance of micro-generation wind projects in the UK with specific focus on the subsidy effect of feed-in tariffs. However, the benefits and cost savings of such projects in Ireland have yet to be clearly identified using empirical data from existing installations. This piece of research attempts to fill the void by examining one such wind energy initiative using empirical data. This longitudinal research study on a $10 \mathrm{~kW}$, three-phase wind turbine took place on a singular farm unit in North County Meath in 2012/2013.

\section{Methodology}

Initially, a site visit to the premises was arranged enabling relevant quantitative data to be obtained from the electrical equipment. Subsequently, a number of electrical utility bills were accessed on-line in agreement with the turbine owner.

\section{A. Evaluation Criteria}

The performance of the Wind Turbine installation was evaluated from the following perspectives:

1) Initial Cost.

2) Power Output.

3) Energy Output.

4) Financial investment appraisal.

\section{B. Schematic Diagram}

The schematic diagram for the wind turbine installation is shown in Fig 1.

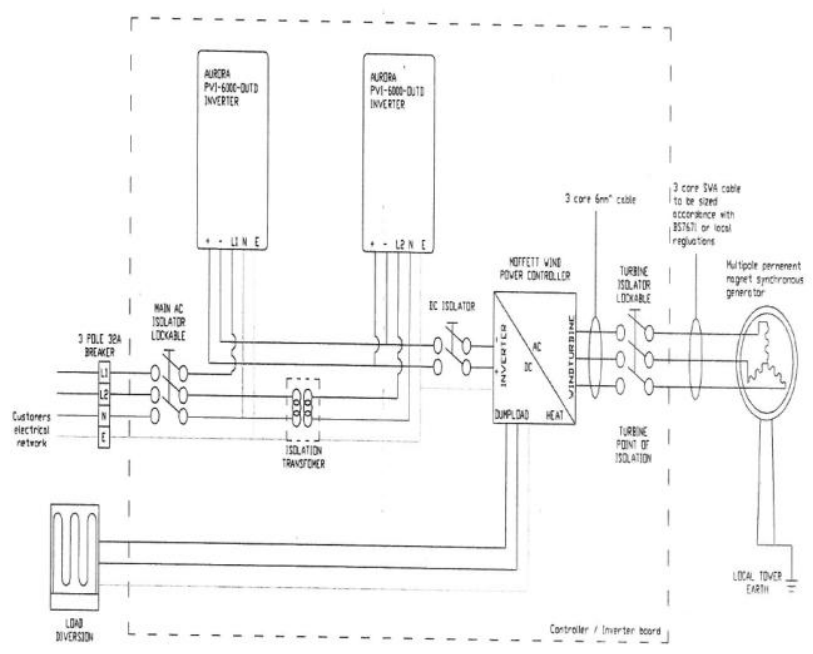

FIG 1. SCHEMATIC DIAGRAM FOR TURBINE INSTALLATION

Figure 1 is a schematic of the design of the system and shows the single-phase AC output from the left-hand inverter connected to $\mathrm{L}_{1}$ while the $\mathrm{AC}$ output from the right-hand inverter connected to $\mathrm{L}_{2}$, via an isolating transformer. The 
inverters are programmed so that the left-hand inverter has priority over the right-hand inverter and therefore will produce an AC output at a lower DC input voltage level and will produce the largest number of energy units. The schematic shows a 3 -core, $6 \mathrm{~mm}^{2}$ Steel Wire Armour (SWA) cable which is buried directly in the ground linking the turbine generator and the farm installation. The distance between these two points is 300 meters.

\section{EVALUATION CRITERIA}

\section{A. Initial Cost}

The turbine installation cost was $€ 22,000$ plus VAT at 21 per cent, making the total price $€ 26,620$. Maintenance of the installation is included in the initial cost. The specification for the turbine is shown in Table 1.

Table 1 Specification for Wind Turbine

\begin{tabular}{|l|l|}
\hline Turbine Type & Upwind \\
\hline Rated Capacity & $10 \mathrm{~kW}$ \\
\hline Maximum Capacity & $12 \mathrm{~kW}$ \\
\hline Rotor Diameter & $6.5 \mathrm{~m}$ \\
\hline Number of Blades & 3 \\
\hline Rotor Speed & $0-260$ RPM \\
\hline Generator Type & Permanent Magnet \\
\hline Cut-in Wind Speed & $2.2 \mathrm{~m} / \mathrm{s}$ \\
\hline Rated Wind Speed & $11 \mathrm{~m} / \mathrm{s}(39 \mathrm{~km} / \mathrm{hr})$ \\
\hline Cut-out Wind Speed & $30 \mathrm{~m} / \mathrm{s}$ \\
\hline Survival Wind Speed & $58 \mathrm{~m} / \mathrm{s}(200 \mathrm{~km} / \mathrm{hr})$ \\
\hline Yaw Control & Active \\
\hline Main Brake & Winch Yaw Control \\
\hline Tower Height & $10 \mathrm{metre}$ \\
\hline Performance & $900-2100 \mathrm{~kW}$ per month \\
\hline
\end{tabular}

This price included the supply and installation of a threephase $12 \mathrm{~kW}$ inverter for the interface between the turbine and the existing electrical installation. However, on a site inspection, it was found that the contracted installation company installed two single-phase $6 \mathrm{~kW}$-rated inverters instead of the quoted three-phase version. The original quote also included installation of a $25 \mathrm{~mm}^{2}$ Steel Wire Armour cable, costing $€ 6.45$ per metre, to carry the current from the turbine to the installation. The installation company were new entrants in the renewable energy industry. They made a strategic decision to enter the renewable energy market after successfully competing in a different industry for a number of years. Before installation began, there was no tests carried out to ascertain the suitability, or otherwise, of the site. This would have included wind speeds tests at the proposed location of the turbine. Also, there were no load (current) tests carried out at the clients existing installation to determine if the loads were balanced equally over the phases.
The three-phase utility meter at the supply intake is equipped with both an Import and an Export facility. Any excess power generated from the turbine, and not used instantaneously on the farm, is exported onto the National Grid. The number of export units is $477 \mathrm{kWh}$ units per annum. The farmer receives $9 \mathrm{cent} / \mathrm{kWh}$ for every unit of energy exported.

The life-span of the turbine is expected to be twenty-five years.

\section{B. Power Output}

The wind turbine has a rated capacity of $10 \mathrm{~kW}$ with a maximum output capacity of $12 \mathrm{~kW}$. The turbine has a rated wind speed of $11 \mathrm{~m} / \mathrm{s}$ as specified in Table 1 .

\section{Energy Output}

Each inverter has an energy output indicator on the front panel. This data is recorded and used in subsequent calculations for this research. Over a three-year period, the two single-phase inverters produced a combined total of $21,779 \mathrm{kWh}$ units of energy. The left-hand inverter, Fig 1, produced 13,307 kWh's and the right-hand inverter produced $8,472 \mathrm{kWh}$ 's of this total. This equates to an average yearly energy output, for the turbine, of 7,260 kWh's. Of this yearly total, $477 \mathrm{kWh}$ units of energy are exported back to the National Grid at a feed-in tariff rate of 9 cent $/ \mathrm{kWh}$. This gives a net import energy saving of $6,783 \mathrm{kWh}$ 's per annum. As a result of examining previous utility bills over a number of years, it is noted that the customer uses 55 per cent of his electricity during the day and 45 per cent at night. Therefore, the actual imported energy savings are $55 \%$ of $6,783(3,731$ kWh's) day units and 45\% of 6,783 (3,052 kWh's) night units. A summary of the yearly savings are as shown in Table 2.

TABLE 2

SAVINGS MADE DUE TO WIND TURBINE INSTALLATION

\begin{tabular}{|c|c|c|c|}
\hline Day Units & Day Rate & $\begin{array}{l}\text { Night } \\
\text { Units }\end{array}$ & $\begin{array}{l}\text { Night } \\
\text { Rate }\end{array}$ \\
\hline \multirow[t]{2}{*}{$3731 \mathrm{kWh}$} & $€ 0.1815$ & $3052 \mathrm{kWh}$ & $€ 0.0897$ \\
\hline & $€ 677$ & & $€ 274$ \\
\hline Plus VAT & $€ 91$ & Plus VAT & $€ 37$ \\
\hline Sub-Total & $€ 788$ & Sub-Total & $€ 311$ \\
\hline
\end{tabular}

Total annual financial benefits $=€ 1,142$

\section{Financial Investment Appraisal}

The turbine installation was a significant investment by the farmer. Given the importance of this investment decision, it is essential to screen the investment proposal. There are four main methods of evaluation used in this research [4]. They are (i) Payback Period (PP), (ii) Accounting Rate of Return 
(ARR), (iii) Net Present Value (NPV), (iv) Internal Rate of Return (IRR).

(i) Payback Period; this is the length of time it takes for the initial investment of $€ 26,620$ to be repaid out of the net cash inflows from the turbine installation. We can derive the payback period by calculating the cumulative cash flows associated with the project. The cumulative cash flow becomes positive after year twenty-three as shown in Fig. 2.

Fig. 2 Payback Period

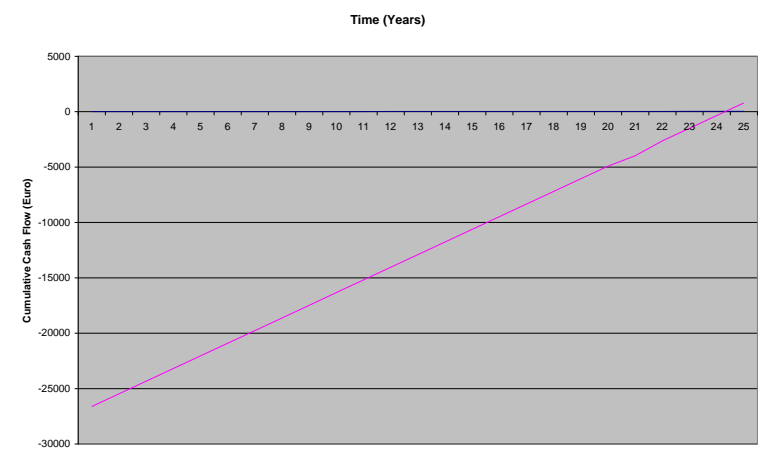

The advantages of the PP method are that it is quick and easy to calculate and is easily understood by the manager making the investment decision.

(ii) Accounting Rate of Return; this investment appraisal method takes the average accounting operating profit that the wind turbine installation generates and expresses it as a percentage of the average investment made over the life-time of the project, i.e. twenty-five years. The average annual operating profit before depreciation over the twenty five years is $€ 1,142$. The turbine is sold at the end of its lifetime for $€ 2,000$. Assuming straight-line depreciation, the annual depreciation charge is $€ 985$ ([26,620 - 2,000]/25). Therefore, the average annual operating profit after depreciation is €157 (€1,142 - €985). The average investment is calculated as [(Cost of Turbine + Disposal value) $/ 2]=€ 14,310$. The ARR of the turbine installation is calculated as $1.1 \% \quad[(€ 157 / € 14,310) \times 100 \%] . \quad$ The ARR relates accounting profit to the cost of the assets invested to generate that profit. The problem with ARR is that it almost completely ignores the time factor. There are also problems concerning the approach taken to derive the average investment of the turbine. (iii) Net Present Value; the NPV investment appraisal method considers all of the costs and benefits of the turbine installation, and makes a logical allowance for the timing of these costs and benefits. The time factor is an important factor as the farmer will not see $€ 1,142$ received now as equivalent in value to $€ 1,142$ receivable in a years' time. The three reasons for this are; (i) Interest lost, (ii) Risk, (iii) Effects of Inflation. The NPV method makes a direct comparison between the sum of the inflows over time and the immediate $€ 26,620$ investment. The cash benefits over time are discounted, depending on the interest rate and the period (year) in which the benefits arise. The discount factor is taken as $13 \%$ and the discount factors are shown in Table 3.

Table 3 Net Present Value

\begin{tabular}{|c|c|c|c|}
\hline Time & Cash Flow & $\begin{array}{c}\text { Discount } \\
\text { Factor } \\
(13 \%) \\
\end{array}$ & $\begin{array}{c}\text { Present } \\
\text { Value }(€)\end{array}$ \\
\hline Immediately & $-€ 26,620$ & 1 & $-€ 26,620$ \\
\hline 1 year's time & $€ 1,142$ & 0.885 & $€ 1,011$ \\
\hline 2 year's time & $€ 1,142$ & 0.783 & $€ 894$ \\
\hline 3 year's time & $€ 1,142$ & 0.693 & $€ 791$ \\
\hline 4 year's time & $€ 1,142$ & 0.613 & $€ 700$ \\
\hline 5 year's time & $€ 1,142$ & 0.543 & $€ 620$ \\
\hline- & - & - & - \\
\hline- & - & - & - \\
\hline- & - & - & - \\
\hline $\begin{array}{l}22 \text { year's } \\
\text { time }\end{array}$ & $€ 1,142$ & 0.065 & $€ 74$ \\
\hline $\begin{array}{c}23 \text { year's } \\
\text { time }\end{array}$ & $€ 1,142$ & 0.060 & $€ 69$ \\
\hline $\begin{array}{c}24 \text { year's } \\
\text { time }\end{array}$ & $€ 1,142$ & 0.053 & $€ 61$ \\
\hline $\begin{array}{c}25 \text { year's } \\
\text { time }\end{array}$ & $€ 1,142$ & 0.047 & $€ 54$ \\
\hline $\begin{array}{c}25 \text { year's } \\
\text { time }\end{array}$ & $€ 2,000$ & 0.047 & $€ 94$ \\
\hline & & NPV & $-€ 18,215$ \\
\hline
\end{tabular}


The NPV of the wind turbine installation is $-€ 18,215$. The decision rule for NPV states that if the NPV is positive, the project should be accepted and if the NPV is negative, the project should be rejected. The NPV method seems to be a better method of appraising the wind turbine installation because it takes into account the following three criteria; (i) The timing of the cash flows, (ii) The whole of the relevant cash flows, (iii) the objectives of the business [4]. In this case, it would appear that investment in the project is not viable because the NPV is a negative value, indicating that the costs outweigh the benefits.

(iv) Internal Rate of Return; The IRR method of investment appraisal, like NPV, involves discounting future cash flows. The IRR of the wind turbine installation is the discount rate that, when applied to its future cash flows, will produce an NPV of precisely zero. In essence, it represents the yield from the turbine investment. From (iii), we calculated the NPV of the installation at an interest rate of 13 per cent as $-€ 18,215$. When the interest rate is set at 2 per cent, the NPV is calculated as $-€ 3,110$. When the interest rate is set at 1 per cent, the NPV is calculated at $€ 80$. Since the IRR is the discount rate that will give an NPV of exactly zero, we can conclude that the IRR of the installation is between 2 per cent and 1 per cent. A more accurate calculation is 1.025 per cent. A table for the IRR calculation is shown in Table 4.

Table 4 Internal Rate of Return

\begin{tabular}{|c|c|}
\hline $\begin{array}{c}\text { Discount } \\
\text { Factor } \\
(\mathbf{2 \% )}\end{array}$ & $\begin{array}{c}\text { Present } \\
\text { Value }\end{array}$ \\
\hline 1 & $\begin{array}{c}- \\
€ 26,620\end{array}$ \\
\hline 0.98 & $€ 1,119$ \\
\hline 0.961 & $€ 1,097$ \\
\hline 0.942 & $€ 1,076$ \\
\hline 0.924 & $€ 1,055$ \\
\hline 0.906 & $€ 1,035$ \\
\hline- & - \\
\hline- & - \\
\hline- & - \\
\hline 0.647 & $€ 739$ \\
\hline 0.634 & $€ 724$ \\
\hline 0.622 & $€ 710$ \\
\hline 0.609 & $€ 695$ \\
\hline 0.609 & $€ 1,218$ \\
\hline$N P V$ & $-€ 3,110$ \\
\hline
\end{tabular}

\begin{tabular}{|c|c|}
\hline $\begin{array}{c}\text { Discount } \\
\text { Factor } \\
(1 \%)\end{array}$ & $\begin{array}{c}\text { Present } \\
\text { Value }\end{array}$ \\
\hline 1 & $\begin{array}{c}- \\
€ 26,600\end{array}$ \\
\hline 0.99 & $€ 1,131$ \\
\hline 0.98 & $€ 1,119$ \\
\hline 0.971 & $€ 1,109$ \\
\hline 0.961 & $€ 1,097$ \\
\hline 0.951 & $€ 1,086$ \\
\hline- & - \\
\hline- & - \\
\hline- & - \\
\hline 0.8 & $€ 914$ \\
\hline 0.795 & $€ 908$ \\
\hline 0.787 & $€ 899$ \\
\hline 0.779 & $€ 889$ \\
\hline 0.779 & $€ 1,558$ \\
\hline NPV & $€ 80$ \\
\hline
\end{tabular}

It is important to note that the methods described, and the values calculated, are not seen purely as a mechanical exercise. The results derived from this wind turbine installation investment appraisal are only one input to the decision-making process. Other, broader, issues that may be connected to the decision include the concern, by the farmer, for our natural environment which, according to much scientific evidence, appear to be under the threat of global warming. It is a hoped that we, at this present time, do not destroy the natural environment to be inhabited by future generations because of our heavy dependence on burning imported fossil fuels. A summary of the results of the financial appraisal methods for the wind turbine installation are expressed in Table 5.

Table 5 Summary of financial appraisal methods

\begin{tabular}{|c|c|c|c|c|}
\hline $\begin{array}{c}\text { Appraisal } \\
\text { Method }\end{array}$ & PP & ARR & NPV & IRR \\
\hline Value & 23 years & $1.1 \%$ & $-€ 18,215$ & $1.025 \%$ \\
\hline
\end{tabular}

\section{FINDINGS}

A potentially significant finding of the study was highlighted by measuring the load current at the Distribution System Operator (DSO) electrical supply intake of the installation. It was found that a possible inefficiency in the design of the installation may have negatively affected the potential for savings on the project. It was noted that the output from the left-hand inverter was connected to $\mathrm{L}_{1}$ of the installation and from the right-hand inverter to $\mathrm{L}_{2}$ as shown in Fig 1 . The only connection to $\mathrm{L}_{3}$ was via the National Grid. However, on analysis of the loads connected to the installation, it was discovered that $\mathrm{L}_{1}$ was the phase with the lightest loads connected to the supply. The problem was compounded because the left-hand inverter was programmed to give the highest output of the two inverters. The result was that the farmer could potentially be exporting electricity via $\mathrm{L}_{1}$ at 9 cent per $\mathrm{kWh}$ and, at the same time, importing electricity on either $\mathrm{L}_{2}$ or $\mathrm{L}_{3}$ at 18 cent per $\mathrm{kWh}$. As a result of this analysis, the output from the left-hand inverter was moved to $L_{2}$ and the output from the right-hand inverter was moved to $\mathrm{L}_{3}$.

The author found that the cable buried directly in the ground, installation method D (British Standard, BS7671, Requirements for Electrical Installations) [5], linking the turbine with the installation is 3 -core $6 \mathrm{~mm}^{2}$ SWA instead of 3 -core $25 \mathrm{~mm}^{2}$ that was on the original quote. Whereas the $6 \mathrm{~mm}^{2}$ cable has a tabulated current of 38 Amps (column 7, Table 4D4A, BS7671) and may be able to carry the maximum current, the volt drop under load needs to be checked. The $\mathrm{mV} / \mathrm{A} / \mathrm{m}$ volt drop for such a $6 \mathrm{~mm}^{2}$ cable is $6.4 \mathrm{mV} / \mathrm{A} / \mathrm{m}$ (column 4, Table 4D4B, [5]). When the cable is carrying, for example, $30 \%$ of the rated output from the turbine, $3.3 \mathrm{~kW}$, this equates to a current value of approximately 13 Amps. Under these conditions, the total volt drop between the start and the end of the cable is 24.96 Volts. If a $25 \mathrm{~mm}^{2}$ cable is used, the total volt drop is 5.85 
Volts $(1.5 \mathrm{mV} \times 13 \times 300)$, a significant improvement in reducing the losses in the cable.

\section{CONCLUSIONS}

From this limited study, it appears that the expected economic benefits of investing in this micro-generation wind energy project did not materialise. The results of the values calculated by the financial appraisal methods are disappointing. An ARR of $1.1 \%$ and a PP of 23 years is unlikely to be acceptable to shareholders in business. As a comparison to generally acceptable economic benefits from investment opportunities, some examples are now briefly discussed. The supermarket giant, Tesco, is in the process of installing voltage optimiser equipment at the DSO intake to nearly all of its 2,300 stores and warehouses in the UK [6]. The equipment reduces the voltage, if required, to allow connected loads run at optimum efficiency. Tesco expects a return on investment of approximately 20 per cent and achieve a payback period of five years by installing the voltage optimizer equipment. Also, Marks and Spencers, the stores chain, has targeted an IRR of between 12 per cent and 15 per cent on any new investment programme [7]. Thirdly, Rolls-Royce in its 2010 annual report and accounts stated that all investments are subject to rigorous examination of risks and future cash flows to ensure that they create shareholder value [8]. Discounted cash flow (NPV) analysis is performed on a regular basis at Rolls-Royce.

The Payback Period of the turbine in this research is significantly longer than that predicted in the research by Kelleher and Ringwood [2]. For example, Kelleher and Ringwood predict a 3.65 years payback period for a Proven $2.5 \mathrm{~kW}$ micro-wind turbine in an open rural area. It must be noted, however, that the range of sizes used in [2] are smaller than the turbine used in this research.

There appears to be several factors contributing to the conclusion that financially the wind turbine project does not perform well in this case.

Firstly, the competencies of some companies' competing in this specialised area would seem to be somewhat questionable. It appears that the installation company in this research did not have the expertise needed to design and install such an installation. They did not complete any preconnection wind speed and/or electrical load tests on the installation and they did not inform the client of the potential pit-falls, or advantages, that his investment might hold. This conclusion concurs with Walters and Walsh [3] who claimed that how the equipment is installed contributes to the success, or otherwise, of the project. In the installation of the wind turbine for this research, two single-phase inverters were installed instead of a three-phase inverter, which may contribute to a lower energy output than specified by the manufacturer. Also, the SWA underground cable linking the turbine generator and the installation appeared to be lower than that needed to efficiently transfer the power between both, considering the distance is significantly long at a length of 300 metres.

Secondly, the renewable energy feed-in tariff is low compared to UK standards, at 9 cent $/ \mathrm{kWh}$. Walters and Walsh [3] concluded that the proposed feed-in tariff of $30.5 \mathrm{p} / \mathrm{kWh}$ would not boost the economic attractiveness of some sites in the UK. There seems little benefit, in Ireland, of customers exporting electricity at significantly lower price per unit than the UK when the higher price is deemed unattractive in the UK. The customer in this study is better advised, from an economic point of view, to use all of his generated units in his installation than export any to the National Grid. Table 6 shows the benefits to the consumer if all the electricity generated by the turbine is used in the installation. We can compare these results with the figures in Table 2.

Table 6 All generated $\mathrm{kWh}$ units used on site

\begin{tabular}{|l|c|}
\hline Day Units & Day Rate \\
\hline $3993 \mathrm{kWh}$ & $€ 0.1815$ \\
\hline & $€ 725$ \\
\hline Plus VAT & $€ 98$ \\
\hline Sub-Total & $€ 823$ \\
\hline
\end{tabular}$\quad$\begin{tabular}{|c|c|c|}
\hline $\begin{array}{c}\text { Night } \\
\text { Units }\end{array}$ & $\begin{array}{c}\text { Night } \\
\text { Rate }\end{array}$ \\
\hline $3267 \mathrm{kWh}$ & $€ 0.0897$ \\
\hline Plus VAT & $€ 40$ \\
\hline Sub-Total & $€ 333$ \\
\hline
\end{tabular}

Total annual financial benefits $=€ 1,156$

When the financial benefits are analysed, allowing for $477 \mathrm{kWh}$ units to be exported to the National Grid as shown in Table 2, it can be concluded that there is very little financial gain to be extracted by using all the generated $\mathrm{kWh}$ units on the installation, as shown in Table 6. The difference in monetary terms is a meager $€ 14$ per annum.

Thirdly, it may be significant that the specialized, and new, nature of these wind energy projects are such, that in many cases a clients' understanding of the venture, its terminology and the technology involved is somewhat limited and therefore the potential for exploitation is great. The investor in this research used his 'gut feeling' in making this investment decision. Larger businesses can afford to employ financial experts to appraise any such potential projects. The main contribution of this research is to provide an appraisal of a small-scale wind turbine installation using actual data from an installed installation which can be used for future, potential, investors in their investment decisions. 
The author feels that there is merit in carrying out an investigation on a similar project where the designer/installer is an expert in the wind energy industry. The results of such an investigation would possibly highlight more favorable results with regard to a small-scale wind turbine investment.

\section{ACKNOWLEDGEMENTS}

Thanks to Gordon Evans for allowing his data to be utilised in this research project.

Thanks also to Malabika Basu for her guidance and support in the write-up of the research results.

\section{REFERENCES}

[1] Department of Communications, Energy and Natural Resources, http://www.dcenr.gov.ie

[2] Kelleher, J. and Ringwood, J.V. (2009) A computational tool for evaluating the economics of solar and wind micro-generation of electricity Energy 34 (4) 401 - 409.

[3] Walters, R. and Walsh, P. R. (2011) Examining the financial performance of micro-generation wind projects and the subsidy effect of feed-in tariffs for urban locations in the United Kingdom. Energy Policy, Volume 39, Issue 9, September, p 5167 - 5181.

[4] Atrill, P. and McLaney, E. Accounting and Finance for NonSpecialists: $7^{\text {th }}$ Edition, Financial Times/Prentice Hall, 2011.

[5] British Standard BS7671:2008 Requirements for Electrical Installations, IEE Wiring Regulations Seventeenth Edition.

[6] Jaggi, R. 'Case study: power efficiency', FT.com, $25^{\text {th }}$ November 2009.

[7] Marks and Spencer plc, Annual Report 2011, page 34.

[8] Rolls-Royce plc Annual Report 2010, page 51. 